\title{
The Effect of the Covid-19 Pandemic on the Crime of Theft
}

\author{
Rahman Syamsuddin ${ }^{1, *}$, Muhammad Ikram Nur Fuady ${ }^{1}$, Muh. Djaelani Prasetya ${ }^{2}$, Andi \\ Anas Chaerul $\mathrm{M}^{1}$ and Kusnadi Umar ${ }^{1}$
}

\author{
${ }^{1}$ Department of Law, Universitas Islam Negeri Alauddin Makassar, Makassar, Indonesia \\ ${ }^{2}$ Department of Law, Universitas Hasanuddin, Makassar, Indonesia
}

\begin{abstract}
This research aims to assist the police institution in preventing theft crimes that increased during the Covid-19 period by mapping areas prone to theft crimes based on the incident's location and the level of intensity of theft crimes. This research is empirical, managed quantitatively by collecting data through documentation and literature study. The results showed an increase in the number of theft crimes by $42.65 \%$ in Makassar City during the six months of the coronavirus pandemic period. This research also succeeded in mapping the locations prone to theft crimes, mostly in residents' homes rather than in the business center, the central area of money circulation. The research results also show that almost all sub-districts in Makassar City are the places where theft crimes occur, dominated by medium and high categories symbolized by red, yellow, and green color. This study recommends that police institutions pay more attention to residential areas, which are the areas where theft crimes most occur during the pandemic period. Furthermore, this research implies that it can become a reference for the police institution to prepare efforts to prevent theft crimes in Makassar City and other areas during the Covid-19 period.
\end{abstract}

Keywords: Covid-19 Period, Makassar City, Police Institution, Theft Crimes.

\section{INTRODUCTION}

The Covid-19 pandemic started in China at the end of 2019 (Chen and Li 2020). Furthermore, the coronavirus spread started to spread to Indonesia and other countries (Fadli 2020). Seeing this, the Chinese government has carried out a massive lockdown in early 2020 to suppress the spread of the virus (Hanming Fang, Long Wang 2020). The implementation of a lockdown-like policy called LargeScale Social Restrictions (PSBB) was also carried out by the Indonesian government from March to June 2020 through Government Regulation Number 21 the Year 2020 concerning Large-Scale Social Restrictions in the Context of Accelerating Handling of Covid-19 (Chryshna 2020). It forces everyone to stay at home for work, and learning activities, including school and college students, are turned online. Not only that, shopping centers and nonessential businesses, such as malls and restaurants, were also closed during the PSBB period, which ended in June 2020 (Santia 2020).

The spread of Covid-19 in Indonesia initially took place in Depok in March 2020, officially announced by President JokoWidodo, which caused an uproar (Ihsanuddin 2020). Furthermore, the spread of the virus began to occur in other areas, which forced the government to classify areas based on the number of Covid-19 sufferers divided into red, yellow, and green zones (Chong 2020). However, not all areas in

*Address correspondence to this author at the Universitas Islam Negeri Alauddin Makassar, Indonesia; Tel: (+62)812 4271641 ;

E-mail: rahman.syamsuddin@uin-alauddin.ac.id
Indonesia are affected by this virus, where there are still some areas that are free from exposure to Covid19 (Shalihah 2020).

The closure of business centers and crowd centers makes calm conditions an excellent opportunity for thieves to commit theft (Clarke, 2012). Police officers have been deployed to provide security, but the ratio of the number of police personnel and the legal area is still not ideal, which makes the chances of crime still high (Movanita 2017). These changes that occurred during the Covid-19 pandemic have brought Indonesia to a new era called the new normal (Muhyidin 2020).

Various crimes were reported during the Covid-19 pandemic, but there was a downward trend in crime rates in most areas. The trend can be seen in the Jakarta City area, which reports decreased crime by around $53.82 \%$, and disturbances of public order decreased by around $34.78 \%$ (Movanita 2020). Furthermore, a decrease in the number of crimes also occurred in Bandung City (Andriyawan 2020) and subdistricts and cities in East Java Province by $62 \%$ (Perdana 2020).

The decline of the crime rate did not only occur in Indonesia but also occurred in various countries of the European continent. For example, UK (Dood 2020) and Poland reported a decrease of up to $50 \%$ in the number of crimes (PAP 2020). Furthermore, large countries such as the United States also reported a decrease in the number of crimes in several major cities, such as Chicago, by $42 \%$ and New York City by $20 \%$ (Coyne 2020). This trend also occurred in 
developing countries around Indonesia, such as Malaysia (Ying 2020), which decreased by $70 \%$, and the Philippines (Huaxia 2020) decreased by $35 \%$.

The downward trend in the number of crimes that occurred during this viral pandemic did not generally occur in Indonesia. One area known for its high crime rate is Makassar City. Although there have been reduced crime rates in other areas, this is different from Makassar City. Reporting of crime cases continues to occur during this pandemic, both through electronic media and printed media. One of the news is from berita55.com (Lam 2020), which reported an increase in violent theft crimes known as "begal" during the corona outbreak that has terrorized the community streets. Also, tagar.id report (Ilham 2020) states that the crime rate in Makassar City increases even though the PSBB policy applies, especially theft crimes that occur in various places, including people's homes. The condition made Makassar City an area where the number of crimes increased during the Covid-19 period.

Interestingly, the theft crimes in Makassar City are that most of the theft crimes are committed in residential areas that are busy living at home due to the PSBB policy. Meanwhile, theft crimes in business centers, such as malls, restaurants, and empty shopping centers, are well preserved. It makes theft crimes, including crimes against property that often occur, even the largest among types of crimes that interfere with human interests in carrying out their activities and disturbing peace and security (Efendi 2014).

In connection with this, it is crucial to know the truth of the increase in theft crimes in Makassar City and the distribution of areas where theft crimes have occurred so that preventive actions can be taken. Makassar City is a metropolitan city as one of the business centers with $1,168,258$ people and a population density of 6,645 people $/ \mathrm{km}^{2}$, making the Makassar City area one of the areas with the highest population density in Indonesia (Selatan 2018). Furthermore, identifying the location of the crime scene in Makassar City, especially theft, will provide mature preparation for police officers and the public to be more vigilant in carrying out their daily activities, so that people can avoid becoming victims of theft crimes. Therefore, this research is a real effort as basic research in helping the police understand the pattern of theft crimes during the Covid19 pandemic, which had changed a lot compared to before the coronavirus emerged.

\section{LITERATURE REVIEW AND HYPOTHESIS DEVELOPMENT}

Based on the results of previous studies, theft crimes can occur because there are opportunities for criminals who provide sufficient space and time to carry out their actions (Clarke, 2012). Besides, the changes that occur due to the permanent application of health protocols in daily life also bring about changes in the community's routine activities, which are increasingly sensitive to others. It can be seen from the application of physical distancing and social distancing, which changes the crowd to lonely in all aspects of life (Felson, Jiang, and Xu 2020). Based on the criminal opportunity theory, the perpetrator of the crime of theft will take advantage of the quiet area conditions, including shopping areas and shopping centers. It is also under the theory of geography crime, which also states that having sufficient space to commit a crime will give rise to a high crime (LeBeau and Leitner 2011)

However, the phenomenon in Makassar City is an exciting thing to study because many sources of information report the increase in the number of theft crimes during the Covid-19 pandemic. Therefore, this research is needed to determine the spike in theft crimes that have occurred where criminals are not afraid of the threat of Covid-19 transmission to continue to haunt the public. Furthermore, we hypothesize that theft crimes that occur in Makassar City have the opportunity to occur based on the presence of space and opportunities that can be seen from the location where the crime of theft occurred during the pandemic, such as residential areas, roads, business centers, and other places. Therefore, geographic mapping of which areas are prone to theft crimes in Makassar City based on potential areas is necessary to assist the police in taking anticipatory steps to prevent theft crimes.

\section{RESEARCH METHODOLOGY}

This research was empirical. The research team took data on the number of theft crimes before the Covid-19 pandemic struck directly at the Makassar City police officers as one of the primary data sources. It was also done because the Indonesian National Police cannot show data on the police institution's website, so a special research permit is required to obtain the data. Next, we extracted data from the Makassar District Court website, which focused on theft crimes in Makassar City based on predetermined intervals, namely during the Covid-19 pandemic, from March to 
August 2020. The data presentation was then managed quantitative from primary data sources (Marshall, Heinzen, and Roberts 2018). Data collection techniques are documentation of primary data at the Police Office in Makassar City and a database on the Makassar District Court website (Marshall et al. 2018). The data obtained will then be managed by researchers who are then presented in table form to obtain the trend of the percentage value of theft crimes and map areas prone to theft crimes (Neuman 2002).

\section{RESULTS AND DISCUSSIONS}

\section{a. The Comparison of the Intensity of Theft Crimes Before and after the Covid-19 Pandemic}

Our research notes focus on the legal area of the Makassar City police. Makassar City consists of 15 sub-districts where each sub-district has a police officer responsible for its area. Data on the number of crimes that occurred will be recorded by each sub-district level police office or Sector Police Office (Polsek); then, every month, it will be reported to the Makassar City Police Office (Polrestabes), which is one level above.

During 2020, when the Covid-19 pandemic hit, data on the number of crimes that occurred at each Polsek was not digitally integrated with the Makassar City Polrestabes, thus demanding that the research team go directly to the Makassar Polrestabes and 14 Polsek offices to collect primary data while still applying the protocol health that is recommended by the government. It is also done because the Indonesian National Police cannot show data on the police institution's website, so a research permit is required to obtain the data.

Based on the results of research at Makassar Polrestabes, it was found that the police institution divided theft crimes into several categories, namely: 1) Ordinary theft; 2) Heavy theft; 3) Violent theft; 4) theft in the family; 5) Animal theft; 6) Motor vehicle theft; 7) Theft of electricity; and 8) Attempted theft. Furthermore, to make it easier to identify the theft crimes that occurred, the data on the eight categories of crimes were combined into theft crimes.

Furthermore, the researchers divided the data focus on theft crimes into two categories based on time. The division is divided into the categories of the period before the Covid-19 pandemic and the period after the Covid-19 pandemic. The category before the Covid-19 pandemic, namely the regular period in which there has been no coronavirus outbreak in Indonesia for 14 months, namely January 2019 to February 2020. Furthermore, the period after the Covid-19 pandemic category called Covid-19 Period is when the coronavirus began to spread in Indonesia until the implementation of the PSBB period in Makassar City, from March 2020 to August 2020, as shown as Table 1 below:

Our team has collected data at the Makassar Police (Polrestabes) office regarding the number of data on theft crimes from January 2019 to February 2020. The data shows that there have been 1,269 cases of theft reported by the community spread across 15 sub-subdistricts of Makassar City. Meanwhile, the number of cases reported during the last six months in 2020 during March to August were 170 cases which we obtained from data from the Makassar Sub-district Court (P. N. Makassar, 2020). If we compare the number of reported theft crimes during the prepandemic period and the Covid-19 pandemic, the following results will be obtained.

Based on these data of Table 1, the results showed the increasing level of theft crimes in the Makassar City area by $42.65 \%$ from the period before the coronavirus spread and during the coronavirus outbreak. It can be seen from the average value of reported theft cases, which increased from 12.07 to 28.3. This value illustrates that the Covid-19 pandemic provides more significant opportunities for criminals, even though the government has made people stay and have home activities through physical distancing, social distancing, and PSBB policies.

Table 1: Comparison of the Number of Theft Crimes in Makassar City

\begin{tabular}{|c|c|c|}
\hline & $\begin{array}{c}\text { Regular Period } \\
\text { (January 2019-February 2020) }\end{array}$ & $\begin{array}{c}\text { Covid-19 Period } \\
\text { (March-August 2020) }\end{array}$ \\
\hline Number of Cases (a) & 1.269 & 170 \\
\hline Number Of Months (b) & 14 & 6 \\
\hline Average Crime Per Month $(c=a / b)$ & 12,07 & 28,3 \\
\hline Percentage of Increase $(12,07 / 28,3)^{\star} 100 \%$ & \multicolumn{2}{|c|}{$42,65 \%$} \\
\hline
\end{tabular}

Source: Primary data managed by researchers. 
This fact is different from what happened in other regions in other countries and other regions in Indonesia. Therefore, research is essential as reference material for the police and government in dealing with theft crimes in Makassar City. This study's results can be used as a reference in preparing strategic materials to deal with thieves during the Covid-19 pandemic.

\section{b. The Distribution Patterns of Theft Crimes}

A crime usually occurs in a particular pattern. Also, preventive measures should be prioritized in preventing the crime rate in urban areas such as Makassar City as the deterrence theory became popular in the 19th century (Raskolnikov 2019). Besides, geographic theory can also be a factor that plays a role in the emergence of theft crimes, especially during the Covid19 pandemic, so this should be tested in today's modern era (LeBeau and Leitner 2011).

This study examines the geographical theory and prevention against theft crimes in Makassar city based on a relatively high increase in the number of crimes, namely $42.65 \%$. Furthermore, we will record the target locations where theft occurs and present it easier to read data. The mapping will help police officers enforce the law and prevent criminals from carrying out their actions. We divided the Makassar City area into 15 sub-sub-districts into several variables targeted by criminals based on data from the Makassar Sub-district Court during the Covid-19 period, from March 2020 to August 2020.

The theft crime target's location variables are roads that accommodate major roads and small roads, then residents' homes, and business centers that include malls, restaurants, and shops. Then, we also found other theft crime targets, such as hospitals, schools, and houses of worship, which we categorized under other variables. The following is the data obtained.
Based on the data obtained from Table 2, the theft crimes in Makassar City can be categorized as occurring in 4 locations. These places are residents' homes, roads, business centers, and others. Residential houses are houses for residents who live in Makassar City, where residents live with their families. The types of houses that are the source of the data are private residences and rental/boarding houses combined into the residential category. The next category is roads, which include arterial roads in the city center and roads in small residential complexes. The business center category, namely malls, restaurants, shops, and shophouses, is the center of money circulation in Makassar City. Finally, there are other categories where the number of cases is minimal, such as houses of worship and hospitals.

The results showed that most theft crimes occurred in people's homes, with $47 \%$. Followed by roads with $27.7 \%$, then business centers at $20 \%$, and others at $5.3 \%$. This result explains that crime in the theory of opportunity where the central business sub-district is a wet area for the circulation of money should be the main target of theft crimes, but in reality, it is not in Makassar City. Moreover, the quiet and even empty conditions due to the PSBB policy in Makassar City should make malls, restaurants, shops, and the like become unguarded, which provides sufficient space for criminals to commit theft.

These results also show that criminals are less interested in central business areas during the Covid19 pandemic, but there are also occurrences, even though they are not as big as residents' homes. Another exciting thing that the condition of the residents' houses, which are busy due to the policy of doing activities at home, is not something that prevents the perpetrators of theft from carrying out their actions. What is more, the threat of contracting the coronavirus if the victim of theft is exposed to Covid-19 is also something that should be a consideration for criminals.

Table 2: Locations of Theft Crimes in Makassar City

\begin{tabular}{|c|c|c|}
\hline & $\begin{array}{c}\text { Covid-19 Period } \\
\text { (March-August 2020) }\end{array}$ & Percentage (\%) \\
\hline \hline Residential Home & 80 & 47 \\
\hline Roads & 47 & 27.7 \\
\hline Business Center & 34 & 20 \\
\hline Others & 9 & 5.3 \\
\hline Total & 170 & 100 \\
\hline
\end{tabular}

Source: Case Tracking Information System (Makassar 2020). 
Therefore, the police institution should pay more attention to residential areas by increasing police officers' number on duty to guard and increase mobile patrols in residential areas to prevent theft crimes.

On the other hand, another favorite location of theft crimes during the Covid-19 pandemic is a road. The road is a means of traffic for people to carry out their activities so that the road is a potential area for crime to occur, theft, and other crimes. During the coronavirus spread in Indonesia, road theft crimes have occurred in 47 cases, or $27.7 \%$ of the total theft crimes. This fact needs to be the attention of the police institution.

Furthermore, the central business area is position three as the theft crime location, with $20 \%$. So far, police officers have focused their guard on the central business area, which is quiet due to the PSBB policy. However, the results of this study provide the fact that this is not entirely true. Therefore, the police institution must immediately improve its strategy in preventing crime to prevent the birth of crime victims. In line with that, there were also locations the crime of theft occurred with a small number with the target of schools, houses of worship, and hospitals, namely $5.3 \%$.

This study also provides an overview of the locations used as a reference for police institutions in detecting theft crimes. The mapping of these locations is based on the results in Table 2, which will then be translated into Makassar City areas based on their subdistricts. The following is a table of the number of crimes by the sub-district in Makassar City.

Furthermore, the data in Table $\mathbf{3}$ are converted into three color categories based on the average number of theft crimes that occur to make it easier to provide a map of areas prone to crime for six months (MarchAugust 2020) Covid-19 pandemic. We divided them into three categories, namely green, yellow, and red. The green color represents an area that is free from theft crimes with an incidence rate of 0 . Furthermore, yellow means an area with a moderate level of theft crimes with an average value interval of theft crimes per month is more than 0 and less than 2. Finally, the red areas represent the high incidence of theft crimes with an average score of more than 2 .

The research team has presented regional data with these color categories in the following figure.

Figure 1 shows the distribution of theft crime areas in Makassar City since the coronavirus broke out. The color category and the zone categorization of the Covid-19 area will also help readers identify areas prone to theft crimes. The figure shows one green category area, ten yellow categories, and four red categories.

Table 3: Location of Theft Crimes by Sub-Sub-District during the Covid-19 Period

\begin{tabular}{|c|c|c|c|}
\hline Sub-district & Number of Theft & Average Per Month & Colour Category \\
\hline \hline Biringkanaya & 12 & 2 & Yellow \\
\hline Bontoala & 4 & 0.67 & Yellow \\
\hline KepulauanSangkarrang & 0 & 1.16 & Yreen \\
\hline Makassar & 7 & 2 & Yellow \\
\hline Mariso & 12 & 1 & Yellow \\
\hline Mamajang & 6 & 2.16 & Red \\
\hline Manggala & 13 & 4.16 & Red \\
\hline Panakukkang & 25 & 1.16 & Yellow \\
\hline Ujung Pandang & 7 & 1 & Yellow \\
\hline Ujung Tanah & 6 & 1.83 & Yellow \\
\hline Tallo & 11 & 3 & Red \\
\hline Tamalanrea & 18 & 2 & Yellow \\
\hline Tamalate & 12 & 4.83 & Red \\
\hline Rappocini & 29 & 1.3 & Yellow \\
\hline Wajo & 8 & & \\
\hline Total & 170 & & \\
\hline Tract & & & \\
\hline
\end{tabular}

Source: Case Tracking Information System (Makassar 2020). 


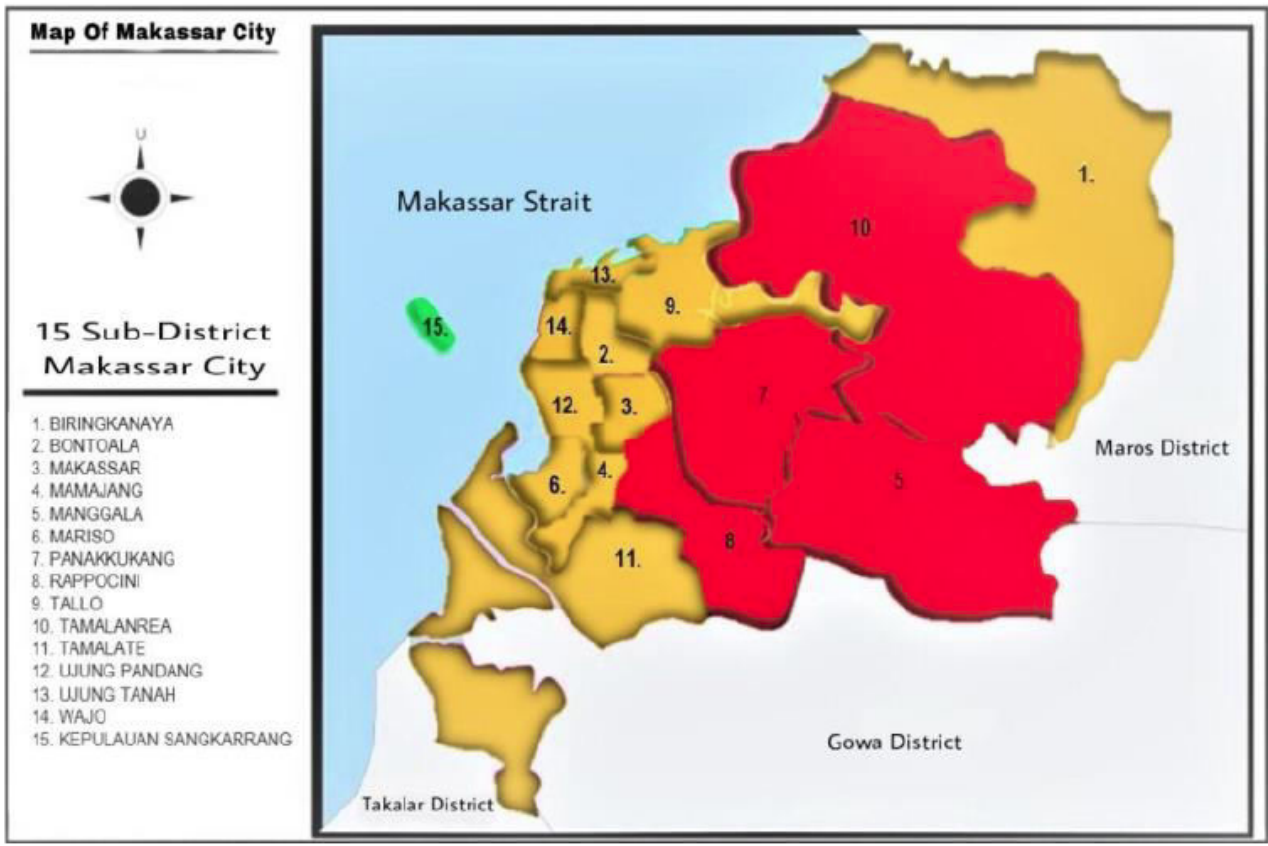

Figure 1: Makassar City, based on the color category of the average occurrence of theft crimes.

Source: Makassar City Government Official Portal (Makassar 2019).

Furthermore, we can conclude that moderate category areas dominate the area of Makassar City with an average rate of theft crimes of 0.1 to 2, represented in yellow in 10 sub-districts. These areas are Biringkanaya, Bontoala, Makassar, Mariso, Mamajang, Ujung Pandang, Ujung Tanah, Tallo, Tamalate, and Wajo. Meanwhile, the red category area means that the rate of theft crimes that occurred during the Covid-19 period is high, with an average of 2 to 4 theft crimes occurring each month. The red category areas are Manggala, Panakukkang, Tamalanrea, and Rappocini.

Then, the research team also saw the distribution of areas in the red category in 4 sub-districts in Makassar City as an area with a large area compared to other sub-districts that are still in the yellow category. We conclude that area size is one of the factors causing the high crime rate during the Covid-19 period, which is supported by a guarding system of one sub-district with one sub-district level police station (Polsek). It is also reinforced by the disparity of police officers' numbers with an area responsible for police custody that occurs nationally, including Makassar City (Movanita, 2017).

The area with the green color category is the Sangkarrang Islands Sub-district, which is a new subdistrict in the archipelago. This area is the only area that is free from the crime of theft. This fact is supported by the location in the form of islands separated from the center of Makassar City on the island of Sulawesi with the smallest population in Makassar City, making it difficult for criminals to commit theft crimes, minimal target victims.

Therefore, the research team concluded that the Covid-19 period influenced the pattern of theft crimes, especially Makassar City. This influence is that theft crimes have occurred in almost all sub-sub-districts in Makassar City, resulting in densely populated areas, such as residential homes. Meanwhile, business centers and highways are fewer favorites for criminals to commit theft, even though the Covid-19 period made the area deserted. The threat of exposure to the coronavirus is also not an obstacle for the perpetrators of theft crimes, as evidenced by the increasing number of theft crimes compared to the regular period. We have also obtained areas prone to theft crimes with green, yellow, and red color categories, which will assist police officers in taking steps to prevent theft crimes so that people can carry out their activities with a comfortable and safe feeling.

\section{CONCLUSION}

This research recommends the police institution to pay more attention to residential areas apart from the central business and other areas. It is following the research results, which shows the large number of theft crimes that occur in residential areas rather than in business centers located in city centers and on highways. Increasing the number of police officers is a 
way that should be taken to balance the size of the area in Makassar City with security officers. Increasing the intensity of security guarding by conducting mobile patrols in residential areas is also necessary to prevent thieves from carrying out their actions based on the results of the mapping of sub-districts in Makassar City based on green, yellow and red categories, especially in densely populated areas that are prone to occur various crimes.

This research is primary research on crime that focuses on the crime of theft. This research can be used to fill the gap between theft crimes that generally occur in central areas of money circulation that have become quiet due to the lockdown policy (PSBB), while the fact is that theft crimes mostly occurred in crowded residential areas during the Covid-19 period. This research can be used by police institutions to assist their duties in preventing and cracking down on criminals in the Covid-19 period. In the future, it can be continued with further research, such as a criminological review of the reasons why criminals commit crimes during the corona outbreak, which can also endanger themselves (the criminals).

\section{ACKNOWLEDGEMENT}

We thank the editors and reviewers for the constructive suggestion on this paper.

\section{REFERENCES}

Andriyawan, Dea. 2020. "Angka Kriminalitas Di Kota Bandung Turun, Tapi Penipuan Online Meningkat." Bandung.Bisnis.Com. Retrieved September 15, 2020 (https://bandung.bisnis.com/ read/20200506/549/1237260/angka-kriminalitas-di-kotabandung-turun-tapi-penipuan-online-meningkat).

Chen, Yu, and Lanjuan Li. 2020. "SARS-CoV-2: Virus Dynamics and Host Response." The Lancet Infectious Diseases 20(5):515516.

https://doi.org/10.1016/S1473-3099(20)30235-8

Chong, Chee-Fah. 2020. "Dividing the Emergency Department into Red, Yellow, and Green Zones to Control COVID-19 Infection; a Letter to Editor." Archives of Academic Emergency Medicine 8(1): e60.

Chryshna, Mahatma. 2020. "Peraturan Pemerintah Tentang PSBB." Kompaspedia. Retrieved September 15, 2020 (https://kompaspedia.kompas.id/baca/data/dokumen/peratur an-pemerintah-tentang-psbb).

Clarke, Ronald. 2012. "Opportunity Makes the Thief." Crime Science $1-9$. https://doi.org/10.1186/2193-7680-1-3

Clarke, Ronald V. 2012. "Opportunity Makes the Thief. Really? And so What?" Crime Science 1(1):3. https://doi.org/10.1186/2193-7680-1-3

Coyne, Marley. 2020. "Crime Rates Across U.S. Drop Amid The Coronavirus Pandemic." Forbes.Com. Retrieved September 15, 2020 (https://www.forbes.com/sites/marleycoyne/2020/ 04/11/crime-rates-across-us-drop-amid-the-coronaviruspandemic/\#6d0cfa2311e3).
Dood, V. 2020. "Crime in UK Falls Sharply since Start of Coronavirus Lockdown." The Guardian. Retrieved (https://www.theguardian.com/uk-news/2020/apr/15/in-ukfalls-sharply-since-start-of-coronavirus-lockdown).

Efendi, Ismu and Jonaedi. 2014. Cepat \& Mudah Memahami Hukum Pidana. Jakarta: Kencana.

Fadli, Rizal. 2020. "Kronologi Lengkap Virus Corona Masuk Indonesia." Halodoc.Com. Retrieved September 9, 2020 (https://www.halodoc.com/artikel/kronologi-lengkap-viruscorona-masuk-indonesia).

Felson, Marcus, Shanhe Jiang, and Yanqing Xu. 2020. "Routine Activity Effects of the Covid-19 Pandemic on Burglary in Detroit, March, 2020." Crime Science 9(1):1-7. https://doi.org/10.1186/s40163-020-00120-x

Hanming Fang, Long Wang, Yang Yang. 2020. HUman Mobility Restrictions And The Spread Of The Novel Corona Virus (2019-NCOV) In China. https://doi.org/10.2139/ssrn.3561645

Huaxia. 2020. "Philippine Crime Drops Nearly 35 Pct amid COVID-19 Lockdown." Xinhua.Net. Retrieved September 15, 2020 (http://www.xinhuanet.com/english/202005/07/c_139038374.htm).

Ihsanuddin. 2020. "Fakta Lengkap Kasus Pertama Virus Corona Di Indonesia." Kompas.Com. Retrieved September 15, 2020 (https://nasional.kompas.com/read/2020/03/03/06314981/fak ta-lengkap-kasus-pertama-virus-corona-diindonesia?page=all)

Ilham, Muhammad. 2020. "Polisi Sebut Kejahatan Begal Di Makassar Meningkat ." Tagar.ld. Retrieved September 15, 2020 (https://www.tagar.id/polisi-sebut-kejahatan-begal-dimakassar-meningkat).

Lam. 2020. "Waspada! Tindak Kejahatan Meningkat Selama Pembatasan Sosial." Berita55.Com. Retrieved September 15, 2020 (https://berita55.com/read-epaper/read/21-042020/waspada-tindak-kejahatan-meningkat-selamapembatasan-sosial).

LeBeau, James L., and Michael Leitner. 2011. "Introduction: Progress in Research on the Geography of Crime." The Professional Geographer 63(2):161-73. https://doi.org/10.1080/00330124.2010.547147

Makassar, Pemerintah Kota. 2019. "Geografis Kota Makassar." Portal Resmi Kota Makassar. Retrieved September 19, 2020 (https://makassarkota.go.id/geografis/).

Makassar, Pengadilan Negeri. 2020. "Sistem Informasi Penelusuran Perkara Pengadilan Negeri Makassar." Sipp-PnMakassar.Go.ld. Retrieved September 16, 2020 (http://sipp.pn-makassar.go.id/list_perkara/search).

Marshall, Brenda, Tom Heinzen, and Katherine Roberts. 2018. Qualitative, Quantitative, and Mixed Methods Research Designs. Fifth Edit. California: SAGE Publications Inc.

Movanita, Ambaranie Nadia Kemala. 2017. "Polri Akui Jumlah Personel Polisi Belum Ideal." Kompas.Com. Retrieved September 15, 2020 (http://nasional.kompas.com/read/ 2017/02/21/16592601/polri.akui.jumlah.personel.polisi.belum ideal).

Movanita, Ambaranie Nadia Kemala. 2020. "Polda Metro Sebut Angka Kejahatan Di Jakarta Turun Selama Pandemi Covid19." Megapolitan.Kompas.Com. Retrieved September 15, 2020 (https://megapolitan.kompas.com/read/2020/04/09/ 18190861/polda-metro-sebut-angka-kejahatan-di-jakartaturun-selama-pandemi-covid).

Muhyidin. 2020. "Covid-19 , New Normal Dan Perencanaan Pembangunan Di Indonesia Covid-19." The Indonesian Journal of Development Planning IV(2):240-52. https://doi.org/10.36574/jpp.v4i2.118

Neuman, W. Lawrence. 2002. Social Research Methods: Qualitative and Quantitative Approaches. Vol. 30. Seventh Ed. England: Pearson Custom Library. https://doi.org/10.2307/3211488 
PAP. 2020. "Crime Rates Drop by 50 Percent during CoronavirusLockdown." Polandin.Com. Retrieved (https://polandin.com/ 47375577/crime-rates-drop-by-50-percent-duringcoronaviruslockdown).

Perdana, Denza. 2020. “Angka Kejahatan Di Jatim Turun Drastis.” Suarasurabaya.Net. Retrieved September 15, 2020 (https://www.suarasurabaya.net/kelanakota/2020/angkakejahatan-di-jatim-turun-drastis-polda-tidak-terapkan-jammalam/).

Raskolnikov, Alex. 2019. Deterrence Theory: Key Findings and Challenges. Vol. 610. 610. Cambridge. https://doi.org/10.2139/ssrn.3460204

Santia, Tira. 2020. "Daftar Mal Yang Terpaksa Tutup Karena Wabah Corona." Liputan6.Com. Retrieved September 15, 2020 (https://www.liputan6.com/bisnis/read/4217539/daftar-malyang-terpaksa-tutup-karena-wabah-corona).

Selatan, Provinsi Sulawesi. 2018. "Profil Kota Makassar." Sulselprov.Go.ld. Retrieved September 16, 2020 (https://sulselprov.go.id/pages/info_lain/22)

Shalihah, Nur Fitriatus. 2020. "Jumlah Berkurang, Berikut Daftar Zona Hijau Corona Di Indonesia." Kompas.Com. Retrieved September 15, 2020 (https://www.kompas.com/tren/read/ 2020/09/11/143000165/jumlah-berkurang-berikut-daftarzona-hijau-corona-di-indonesia?page=all).

Ying, Teoh Pei. 2020. "70 per Cent Drop in Crime Rate in Malaysia." Nst.Com.My. Retrieved September 15, 2020 (https://www.nst.com.my/news/nation/2020/03/578036/70cent-drop-crime-rate)

Received on 10-12-2020

Accepted on 26-01-2021

Published on 01-02-2021

DOI: https://doi.org/10.6000/1929-4409.2021.10.37

(C) 2021 Syamsuddin et al.; Licensee Lifescience Global.

This is an open access article licensed under the terms of the Creative Commons Attribution Non-Commercial License (http://creativecommons.org/licenses/by-nc/3.0/) which permits unrestricted, non-commercial use, distribution and reproduction in any medium, provided the work is properly cited. 